\title{
KEPEMIMPINAN KEPALA MADRASAH DALAM LEMBAGA PENDIDIKAN ISLAM
}

\author{
Ahmad Noviansah \& Mizaniya \\ UIN Sunan Kalijaga Yogyakarta \\ 19204080012@student.uin-suka.ac.id,19204080018@student.uin-suka.ac.id
}

\begin{abstract}
This research is motivated by one of the key factors in supporting the success of madrasas with achievements is the leadership or management of madrasab principals. The quality of a madrasa leader is the key to the success of education in this educational institution. leadership style encompasses how a person acts in an organizational context Good leadership is always associated with school success. There is a significant correlation between school performance and the effectiveness of a leader. Edmonds mentioned that a good school is led by a good leader. Still in line, Rutherford stated that effective leaders always have a clear vision, so he also has a work program. Meanwbile, Rutter, as quoted by Sergiovanni, stated that the main is the key to the success and improvement of the quality of their students. However, to become a good leader is not only due to the prize factor, but also requires strong effort. A leader's cultural and social background and school become a very influential factor on the main leadership, it explains the social development of school residents and the leader's cultural and social background then becomes a necessity to express the success of an educational institution, such as Madrasas. This study aims to determine Islamic leadership in terms of theological perspective. The research method in this article is library research research using qualitativeinterpretative data presentation. The research results of this journal are the Teacher as a leader in Islamic education with various terms that have moral, professional, and spiritual implications.
\end{abstract}

Keywords: Islamic Leadership, Theological Perspective

\begin{abstract}
Abstrak : Penelitian ini dilatarbelakangi oleh salah satu faktor kunci dalam menunjang keberhasilan madrasah berprestasi adalah kepemimpinan atau manajemen kepala madrasah. Kualitas seorang pemimpin madrasah menjadi kata kunci keberhasilan pendidikan di lembaga pendidikan ini. gaya kepemimpinan mencakup tentang bagaimana seseorang bertindak dalam konteks organisasi Kepemimpinan yang baik selalu dikaitkan dengan keberhasilan sekolah. Ada korelasi yang signifikan antara sekolah kinerja dan efektivitas seorang pemimpin. Edmonds menyebutkan bahwa sekolah yang baik dipimpin oleh seorang pemimpin yang baik. Masih sejalan, Rutherford menyatakan bahwa pemimpin yang efektif selalu memiliki visi yang jelas, sehingga ia juga memiliki program kerja. Sedangkan Rutter, seperti dikutip oleh Sergiovanni, menyatakan bahwa utama adalah kunci keberhasilan dan peningkatan kualitas siswanya. Namun, untuk menjadi seorang pemimpin yang baik bukan hanya karena faktor hadiah, tetapi juga membutuhkan usaha yang kuat. Seorang pemimpin "s latar belakang budaya dan sosial dan sosial sekolah menjadi faktor yang sangat berpengaruh terhadap kepemimpinan utama, itu menjelaskan pembangunan sosial warga sekolah dan pemimpin "s latar belakang budaya dan sosial kemudian menjadi suatu keharusan untuk mengungkapkan keberhasilan suatu lembaga pendidikan, seperti Penelitian ini bertujuan
\end{abstract}

Islamika : Jurnal Keislaman dan Ilmu Pendidikan

Volume 3, Nomor 1, Januari 2021; 1-20

https:// ejournal.stitpn.ac.id/index.php/islamika 
untuk mengetahui kepemimpinan Islam yang ditinjau dari perspektif teologis. Metode penelitian dalam artikel ini ialah penelitian library research dengan menggunakan penyajian data kualitatif-interpretatif.Hasil penelitian dari jurnal ini adalah Guru sebagai pemimpin dalam pendidikan Islam dengan berbagai istilah yang digunakannya memiliki implikasi dan konsekuensi moral, profesional, dan spiritual.

Kata Kunci: Kepemimpinan Islam, Perspektif Teologis

\section{PENDAHULUAN}

Madrasah merupakan lembaga pendidikan Islam yang tumbuh dan berkembang dari, oleh dan untuk masyarakat Islam. Masyarakat baik secara individu maupun organisasi membangun madrasah untuk memenuhi kebutuhan pendidikannya, sehingga tidak heran jika madrasah tersebut memakai tempat apa adanya. Semangat keagamaan atau da'wah menjadi modal utama mereka membangun madrasah. Hingga saat ini lebih dari 96\% jumlah madrasah yang ada di Indonesia adalah milik swasta, sedangkan sisanya, kurang dari 4\% berstatus negri. Dari 6.671 di Jawa Timur pada tahhun 2006, hanya 2,16\% (143) yang berstatus negeri, sisanya $97,84 \%$ (6.474) berstatus swasta.

Semangat keagamaan dan dakwah tersebut harus berhadapan dengan tuntutan baru terutama menyangkut pemberlakuan Peraturan Pemerintah Nomor 19 tahun 2005 tentang Standar Nasional Pendidikan (sekarang lahir PP 32/2013 tentang standar nasional pendidikan menggantikan PP yang lama), yang diikuti dengan beberapa Permendiknas sebagai penjabaran dari PP tersebut. Standar nasional pendidikan adalah kriteria minimal tentang sistem pendidikan di seluruh wilayah hukum NKRI, yang terdiri atas 8 (delapan) standar, yaitu: standar isi, standar proses, standar kompetensi lulusan, standar pendidik \& tenaga kependidikan, standar sarana dan prasarana, standar pengelolaan, standar pembiayaan, dan standar penilaian pendidikan. Dengan demikian, setiap madrasah dituntut dapat memenuhi standar tersebut untuk dapat dikatakan sebagai madrasah berprestasi, bahkan berusaha meningkatkan kualitasnya ke standar yang lebih tinggi.

Salah satu faktor kunci dalam menunjang keberhasilan madrasah berprestasi adalah kepemimpinan atau manajemen kepala madrasah. Madrasah-madrasah yang selalu meningkatkan prestasi kerjanya adalah yang dipimpin oleh kepala madrasah 
yang baik. Organisasi yang dinamis senantiasa dipimpin oleh pemimpin yang baik, yaitu pemimpin yang selalu berupaya meningkatkan prestasinya (Edmonds, 1979).

Kualitas seoarang pemimpin merupakan kata kunci dalam sebuah madrasah untuk saat ini. Beberapa modal dasar yang harus dimiliki oleh pemimpin pendidikan (madrasah), yaitu: 1) bersedia mengambil resiko; 2) selalu menginginkan pembaharuan; 3) bersedia mengatur dan mengurus; 4) mempunyai harapan yang tinggi; 5) bersikap positif; dan 6) berani tampil dan berada di muka. Pengembangan madrasah berprestasi tidak bisa dilepaskan dari peran kepala madrasah yang memiliki keenam modal dasar tersebut (Muhaimin, 2006).

Lebih dari itu, Islam sebagai agama yang sempurna telah mengatur dan memberikan rambu-rambu terhadap manusia yang notabenenya di samping sebagai abd juga sebagai khalifah fi al-ardh. Peran dan fungsi yang dimainkan oleh manusia di muka bumi ini sesungguhnya adalah manifestasi dari kedua posisi tersebut. Secara khusus, tulisan ini mengungkap kerangka kepimimpinan kepala madarasah dalam lembaga islam, yaitu kepemimpinan pendidikan di madrasah sehingga aktualisasi diri manusia dalam hal ini menemukan justifikasinya.

\section{METODE PENELITIAN}

Penelitian ini merupakan jenis penelitian library research dengan menggunakan penyajian data kualitatif-interpretatif dimana objek utamanya adalah buku-buku dan artikel-artikel yang berkaitan dengan penelitian ini. Penelitian ini dilakukan menggunakan prosedur: pengumpulan, analisis dan penyajian data, yaitu data primer dan data sekunder. Data primer dalam penelitian ini diperoleh dari buku-buku yang menyangkut tentang islam seperti kitab-kitab ulama'-ulama' salaf yang berjudul: Falsafah Al-Tarbiyah Fi al-Quran Al-karim yang ditulis oleh Ai Khalil Abu Al'Ainain, sedangkan data sekundernya yaitu yang didapatkan melalui jurnal, artikel yang membahas kepemimpinan dan teologi islam. 


\section{HASIL DAN PEMBAHASAN}

\section{Kepemimpinan Dalam Pendidikan Islam}

\section{A. Makna Kepemimpinan}

Kepemimpinan sebagaimana dikatakan Stogdill yang dikutip K. Permadi adalah suatu proses mempengaruhi aktivitas kelompok dalam rangka perumusan dan pencapaian tujuan (Permadi, 1996). Sedang Stephen P. Robbins mengemukakan bahwa "Leadership is ability to influence group a certain to purpose the the goal achievement" kepemimpinan adalah kemampuanm mempengaruhi suatu kelompok ke arah pencapaian tujuan. Pendapat ini memandang semua anggota kelompok atau organisasi sebagai satu kesatuan, sehingga kepemimpinan diberi makna sebagai kemampuan mempengaruhi semua anggota atau kelompok agar bersedia melakukan kegiatan untuk mencapai tujuan organisasi (Robbins, 1991). Pendapat lain juga mendefinisikan tentang kepemimpinan adalah suatu kekuasaan untuk memepengaruhi sesorang untuk mengerjakan atau tidak mengerjakan sesuatu. Untuk itu, kepemimpinan membutuhkan penggunaan kemampuan secara aktif untuk mempengaruhi pihak lain dan dalam mewujudkan tujuan organisasi yang telah ditetapkan (Umam,2010).

Hal senada sebagaimana dikemukakan Nanang Fattah, bahwa seorang pemimpin ada hakekatnya adalah seseorang yang mempunyai kemampuan untuk mempengaruhi perilaku orang lain di dalam kerjanya dengan menggunakan kekuasaan. Sedang kekuasaan adalah kemampuan untuk mengarahkan dan mempengaruhi bawahan sehubungan dengan tugas-tugas yang harus dilaksanakan (Fattah, 2004).

Dengan demikian pemimpin diharapkan mampu menciptakan perubahan yang signifikan dalam organisasi dan bukan mempertahankan status quo. Sementara perubahan bukan merupakan sesuatu yang diinginkan pimpinan, tetapi lebih pada tujuan (purposes) yang diinginkan dan dimiliki bersama yang diharapkan harus dicapai di masa depan sehingga tujuan menjadi motivasi utama visi dan misi organisasi.

Dari uraian tujuan kepemimpinan memberikan indikasi bahwa seseorang pemimpin berfungsi sebagai orang yang mampu menciptakan perubahan secara 
efektif dan menggerakkan orang lain untuk mau melakukan yang dikehendaki oleh pemimpin.

\section{B. Perbedaan Antara Pemimipin dan Manajer}

Terdapat perbedaan pengertian dan saling berhubungan antara pemimpin dan manager, serta antara kepemimpinan dan manajement:

Pertama, mengenai pemimpin dan manajer. Beberapa buku tentang kepemimpinan mengemukakan bahwa perbedaan antara dan manajer tampak dari kompetensi ataupun perannya masing-masing, yaitu pemimpin adalah orang yang dapat menentukan secara benar apa yang harus dikerjakan; sedangkan manajer adalah orang yang dapat mengerjakan tugas dan tanggung jawab yang ditentukan. Leaders are people who do the right thing; sedangkan managers are people who do the things right (Warren Bennis, 2000).

Sementara itu, Zales Nick membedakan manager dan leader sebgai berikut: "Leaders "think about goals in a way that creates images and expectations about the direction a business should take. Leaders influence changes in the way people think about what is desirable, possible or necessary"; managers, "on the other hand tend to view work as a means of achieving goals based on the action taken by workers".

Dalam membandingkan antara pemimpin dan menejer, Robert Haller mengidentifikasi perbedaan-perbedaan berikut. Pemimpin menurutnya mempunyai karakteristik:

"Administer, originite, develop, inspire trust, think long terms, ask what and why, watch the horizon, challenge status quo, are their own people, do the right thing"; sedangkan manajer mempunyai karakteristik "implement, copy, maintain, control, think short term, ask how and whwn, watch bottom line, accept status quo, are good soldiers, do the things right" (Robert Heller, 1999).

Tokoh lain, seperti dikatakan oleh Trompenaars dan Hampden-Turner (2001) secara aktraktif membedakan keduanya dengan ungkapan:

"The main difference between managers and leaders is that some managers cannot sleep because they have not met their objectives, while some leaders cannot sleep because they various objectives appears to be inconflict and they cannot reconcile them"; It goes without saying that when objectives clash and impede one another, they will be difficult to attain, and no one will sleep" 
Kedua, mengenai kepemimpinan dan manajemen. Kepemimpinan dan manajemen adalah 2 (dua) konsep yang berbeda namun saling melengkapi, bukan mengganti. Persamaannya terletak pada pencapaian keberhasilan atau sukses organisasi. Sedangkan perbedaannya terletak pada fungsi dan aktivitasnya. Sebagaimana dikemukakan oleh Schon (1984) bahwa kepemimpinan dan manajemen bukankah merupakan terma yang sinonim. Seseorang bisa menjadi pemimpin tanpa harus menjadi manajer. Seseorang bisa melaksanakan.

Fungsi-fungsi simbolik, inspirasional, edukasional dan normatif pemimpin yang mempresentasikan kepentingan organisasi tanpa harus melaksanakan tugas formal manajemen. Sebaliknya, seseorang bias memanage tanpa harus memimpin. Seseorang individu bisa memonitor dan mengontrol aktivitas-aktivitas organisasional, membuat keputusankeputusan, dan mengalokasikan sumber sumber daya tanpa harus melaksanakan fungsi-fungsi simbolik, normatif, inspirasional, edukasional kepemimpinan.

\section{Kedudukan Pemimpin}

Kedudukan pemimpin adalah kedudukan wali (wakil). Kualitas terpenting pemimpin adalah dua, yaitu adil dan memandu. Dua kualitas ini merupakan tujuan utama, sehingga pemimpin dapat menegakkankeadilan. Pemimpin diharapkan sebagai orang yang mengajak rakyat pada kebaikan dan sebagai lampu pencerah. Dari sudut pandang keadilan, pemimpin adalah pelindung dan pengawas. Dari sudut pandang bimbingan atau panduan, pemimpin adalah kepala. Dari kedua sudut itu pemimpin adalah model dan teladan. Kepribadiannya merupakan perwujudan sempurna keadilan maupun perwujudan sempurna kemajuan, kematangan, dan kepemimpinan yang baik.

Hal yang paling relevan berkenaan dengan pemimpin kebutuhan apa yang dipenuhi. Empat tugas pemimpin dalam kerangka teologis adalah: bidang keagamaan, pemimpin politik, menegakkan keadilan, dan mengawasi kondisi serta konsepsinya. Pemimpn dalam pengertian perwalian spiritual menunjukan arti penting manusia, dan karna itu pembehasannya mengenai manusia sesunggunnya manusia mempunyai dua kehiudupan, kehidupan spritual dan kehidupan non spiritual. Kedua kehidupan ini aktual. Kehidupan spritual manusia adalah suatu yang rill atau fenomenal. 


\section{Kriteria Seorang Pemimpin}

Terdapat beberapa Kriteria khusus seorang pemimpin seperti berikut ini:

Pertama, kemampuan. Seorang pemimpin dalam suatukomunitas harus memiliki keunggulan dalam bidang garapan yang dipimpinnya. Sebab hal ini akan berimplikasi pada prestasi kerja yang akan dicapainya. Seorang pemimpin dalam suatu perusahaan telekomunikasi, misalnya, harus seseorang yang memiliki kapasitas dalam lapangan yang dipimpinnya. Ia akan dituntut kerja professional untuk mencapai tujuan maksimal.

Kedua, dukungan dan kecintaan dari bawahannya. Dalam manajemen modern dikenal istilah kerja kolektif dengan mendasarkan pada hanya akan terjadi dalam iklim kepemimpinan yang satu sama lain terbangun sikap saling menghargai dan mencintai.

Ketiga, terdiri dari orang-orang yang terbaik. Terbaik secara moral berbeda dengan "terbaik" berdasarkan kepentingan politik. Oleh karena itu dibutuhkan kemampuan untuk menjaring bakal pemimpin yang terbaik secara moral maupun sosial. Sebab pemimpin dalam banyak hal merupakan juru bicara bagi komunitas yang dipimpinnya. Ia merupakan representasi berbagai keinginan atau cita-cita institusi yang dikelolanya.

Keempat, berakhlak takwa sebagaimana firman Allah dalam al-Qur'an surat al-Anfal: 34:

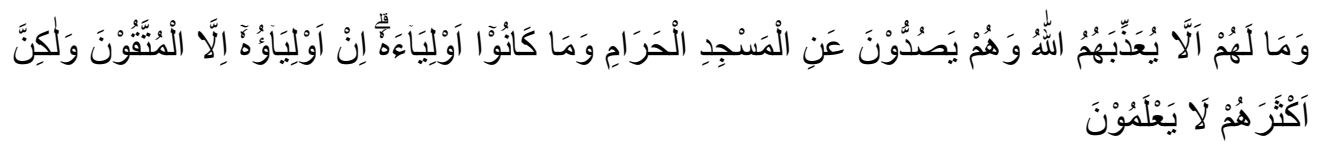

"Dan mengapa Allah tidak menghukum mereka padahal mereka menghalang halangi (orang) untuk (mendatangi) Masjidilharam dan mereka bukanlah orang orang yang berhak menguasainya? Orang yang berhak menguasai (nya), hanyalah orang-orang yang bertakwa, tetapi kebanyakan mereka tidak mengetahui."

Terutama dalam menegakkan shalat dan zakat sebagaimana firman allah dalam al-Qur'an surah al-Maidah: 54-55:

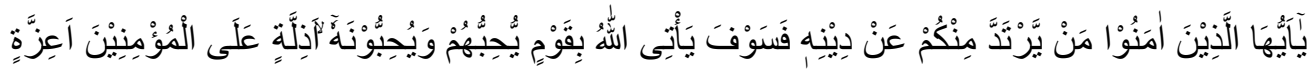

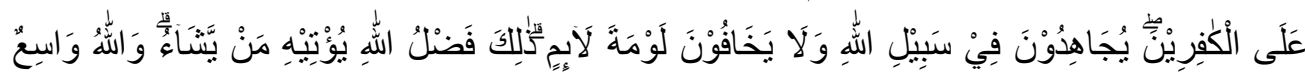

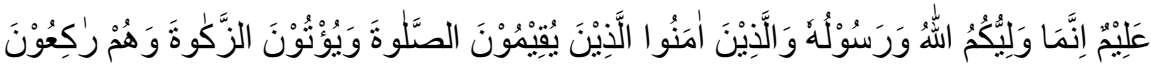


"Wahai orang-orang yang beriman! Barangsiapa di antara kamu yang murtad (keluar) dari agamanya, maka kelak Allah akan mendatangkan suatu kaum, Dia mencintai mereka dan mereka pun mencintai-Nya, dan bersikap lemah lembut terhadap orang-orang yang beriman, tetapi bersikap keras terhadap orang-orang kafir, yang berjihad di jalan Allah, dan yang tidak takut kepada celaan orang yang suka mencela. Itulah karunia Allah yang diberikan-Nya kepada siapa yang Dia kehendaki. Dan Allah Mahaluas (pemberian-Nya), Maha Mengetahui. Sesungguhnya penolongmu hanyalah Allah, Rasul-Nya, dan orang-orang yang beriman, yang melaksanakan salat dan menunaikan zakat, seraya tunduk (kepada Allah)".

Sifat-sifat seperti ini diperlukan terutama untuk memberikan nilai (value) terhadap pekerjaan yang digelutinya, sehingga kerja tidak semata-mata mencari keuntungan, tetapi juga memiliki semangat pengabdian yang tinggi. Akhlak dan takwa juga mencerminkan kualitas keberagamaan seseorang yang pada gilirannya akan menjadi kendali moral dari proses kepemimpinan yang diperankannya.

Ciri-ciri kepemimpinan seperti disebutkan di atas, pada dasarnya mengilustrasikan sosok pemimpin yang cerdas, berkualitas, akomodatif, dan sarat nilai. Keutuhan setiap komponen kepemimpinan tersebut akan berpengaruh pada kemampuan berpikir dan bersungguhsungguh, terutama dalam proses pemecahan masalah-masalah yang melilit masyarakat atau institusi yang dipimpinnya. Kepemimpinan ini adalah sesuatu yang luhur. Ia merupakan salah satu pilar pembangunan masyarakat yang tidak bisa dinafikkan. Ia harus selalu ada selama komunitas manusia itu ada.

\section{E. Kepemimpinan Sebagai Suatu Gaya}

Mungkin karena keputusan dalam mendefinisikan kepemimpinan, para teoritisi manajemen berusaha menggambarkannya dalam gaya. Dalam menggunakan istilah yang luas seperti itu mereka mencoba menggambarkan bagaimana orang tersebut bertindak, bukan siapakah orang tersebut. Bila ada yang berpikir mengenai sejumlah pemimpin yang dikenal secara pribadi, mungkin dapat disimpulkan sendiri mengenai gaya mereka. "Ia tipe seorang pemain/pelatih", atau "Ia seorang primadona", atau "Ia seorang pemain tunggal”. Dengan kata lain, ada kecenderungan untuk menggolongkan seorang 
pemimpin berdasarkan cara ia memimpin menurut cara pandang sesorang mengenai dia. Dengan sendirinya, seseorang mungkin berbeda pendapat dengan orang lain mengenai gaya seorang pemimpin. "Gaya" ternyata merupakan ringkasan dari bagaimana seorang pemimpin melaksanakan fungsi kepemimpinannya dan bagaimana ia dilihat oleh mereka yang berusaha dipimpinnya atau mereka yang mungkin sedang mengamati dari luar.

Kepemimpinan meliputi proses mempengaruhi dalam menentukan tujuan organisasi, memotivasi perilaku pengikut untuk mencapai tujuan, mempengaruhi untuk memperbaiki kelompok dan budayanya. Kepemimpinan mempunyai kaitan yang erat dengan motivasi. Hal tersebut dapat dilihat dari keberhasilan seorang pemimpin dalam menggerakkan orang lain dalam mencapai tujuan yang telah ditetapkan sangat tergantung kepada kewibawaan, dan juga pimpinan itu dalam menciptakan motivasi dalam diri setiap orang bawahan, kolega, maupun atasan pimpinan itu sendiri.

\section{F. Gaya Kepemimpinan}

Karena gaya kepemimpinan mencakup tentang bagaimana seseorang bertindak dalam konteks organisasi tersebut, maka cara termudah untuk membahas berbagai jenis gaya ialah dengan menggambarkan jenis organisasi atau situasi yang dihasilkan oleh atau yang cocok bagi satu gaya tertentu (Robert D. Dale, 1992).

Setidaknya terdapat lima gaya kepemimpinan, yaitu: 1) birokratis; 2) permisif (serba membolehkan); 3) laissez-faire (berasal dari bahasa Perancis yang sejatinya menunjuk pada doktrin ekonomi yang menganut paham tanpa campur tangan pemerintah di bidang perniagaan; sementara dalam praktik kepemimpinan, si pemimpin mengarahkan orang-orang yang dipimpinnya untuk melakukan apa saja yang mereka kehendaki); 4) partisipatif; dan 5) otokratis (Keating, 1990).

Berikut penjelasan masing-masing gaya tersebut di atas menurut cara kerja pemimpinnya dalam organisasi:

a) Birokratis adalah satu gaya yang ditandai dengan keterikatan yang terusmenerus kepada aturan-aturan organisasi. Gaya ini menganggap bahwa kesulitan-kesulitan akan dapat diatasi bila setiap orang mematuhi peraturan. 
Keputusan-keputusan dibuat berdasarkan prosedur prosedur baku. Pemimpinnya adalah seorang diplomat dan tahu bagaimana memakai sebagian besar peraturan untuk membuat orang-orang melaksanakan tugasnya. Kompromi merupakan suatu jalan hidup karena untuk membuat satu keputusan diterima oleh mayoritas, orang sering harus mengalah kepada yang lain.

b) Permisif, memiliki keinginan untuk membuat setiap orang dalam kelompok tersebut puas. Membuat orang-orang tetap senang adalah aturan mainnya. Gaya ini menganggap bahwa bila orang-orang merasa puas dengan diri mereka sendiri dan orang lain, maka organisasi tersebut akan berfungsi dan dengan demikian, pekerjaan akan bisa diselesaikan. Koordinasi sering dikorbankan dalam gaya ini.

c) Laissez-faire bukanlah gaya kepemimpinan. Gaya ini membiarkan segala sesuatunya berjalan dengan sendirinya. Pemimpin hanya melaksanakan fungsi pemeliharaan saja. Misalnya, seorang pemimpin mungkin hanya namanya saja ketua dari organisasi tersebut dan hanya menangani urusan penting, sementara yang lainnya mengerjakan segala pernik mengenai bagaimana organisasi tersebut harus beroperasi. Gaya ini kadang-kadang dipakai oleh pemimpin yang sering bepergian atau yang hanya bertugas sementara. Gaya kepemimpinan ini disebut pula sebagai gaya kepemimpinan kendali bebas. Pemimpin memberikan kekuasan penuh terhadap bawahan, struktur organisasi bersifat longgar dan pemimpin bersifat pasif.

d) Partisipatif, Gaya kepemimpinan ini dipakai oleh mereka yang percaya bahwa cara untuk memotivasi orang-orang adalah dengan melibatkan mereka dalam proses pengambilan keputusan. Hal ini diharapkan akan menciptakan rasa memiliki sasaran dan tujuan bersama. Masalah yang timbul adalah kemungkinan lambatnya tindakan dalam menangani masa-masa krisis. Gaya kepemimpinan model ini dapat pula disebut gaya kepemimpinan demokrasi yang ditandai dengan adanya suatu struktur yang pengembangannya menggunakan pendekatan pengambilan keputusan yang kooperatif. Di bawah kepemimpinan demokratis cenderung bermoral tinggi dapat bekerjasama, mengutamakan mutu kerja dan dapat mengarahkan diri sendiri. 
e) Otokratis, Gaya otokratis ditandai dengan ketergantungan kepada yang berwenang dan biasanya menganggap bahwa orang-orang tidak akan melakukan apa-apa kecuali jika diperintahkan. Gaya ini tidak mendorong adanya pembaruan. Pemimpin menganggap dirinya sangat diperlukan. Keputusan dapat dibuat dengan cepat. Selain itu kepemimpinan dengan gaya Otokratis menggunakan metode pendekatan kekuasaan dalam mencapai keputusan dan pengembangan strukturnya. Jadi kekuasaanlah yang sangat dominan diterapkan.

\section{Kerangka Teologis Kepemimpina}

Secara moral, kepemimpinan berkaitan erat dengan tugas dan fungsi manusia di muka bumi ini. Di antara tugas dan fungsi kelahirannya ke muka bumi ini adalah memelihara dan mendayagunakan sumber daya alam untuk kesejahteraan umat manusia. Manusia diciptakan sebagai khalifah Allah di muka bumi. Allah berfirman:

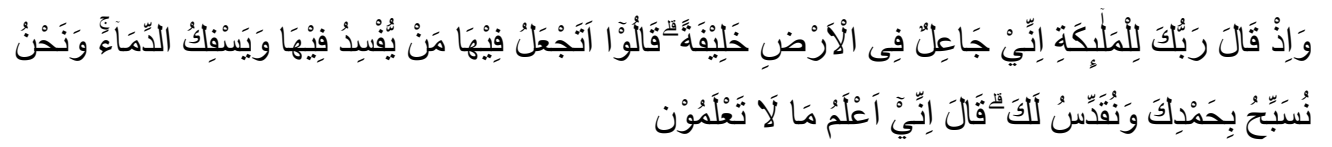

"Dan (ingatlah) ketika Tuhanmu berfirman kepada para malaikat, "Aku hendak menjadikan khalifah di bumi." Mereka berkata, "Apakah Engkau hendak menjadikan orang yang merusak dan menumpahkan darah di sana, sedangkan kami bertasbih memuji-Mu dan menyucikan nama-Mu?" Dia berfirman, "Sungguh, Aku mengetahui apa yang tidak kamu ketahui." (QS. Al. Baqarah:30).

Manusia menjadi pemimpin sekaligus pemelihara bukan saja untuk komunitas manusia, tetapi juga untuk kepentingan segala bentuk makhluk yang diciptakan-Nya. Manusia diciptakan untuk menjadi pemimpin dan pemelihara agar mampu memelihara bumi dan langit beserta seluruh ciptaan yang ada di antara keduanya, minimal menjadi pemimpin bagi diri mereka sendiri. Selain itu manusia diharapkan tidak membuat kerusakan di muka bumi sehingga mengganggu keseimbangan alam. Firman Allah dalam al-Qurean:

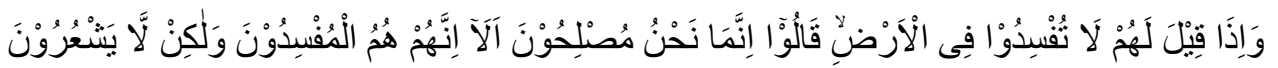


"Dan apabila dikatakan kepada mereka, "Janganlah berbuat kerusakan di bumi!" Mereka menjawab, "Sesungguhnya kami justru orang-orang yang melakukan perbaikan.'Ingatlah, sesungguhnya merekalah yang berbuat kerusakan, tetapi mereka tidak menyadari. (Qs. Al-Baqarah: 11-12).

Makna yang terkandung dalam kedua ayat tersebut merupakan kerangka teologis yang diyakini sebagai doktrin kekhalifahan, sehingga secara praktis ia berimplikasi pada keharusan memilih seorang pemimpin yang tidak berbuat kerusakan di muka bumi. Bahkan, dengan dukungan interpretasi ayat-ayat lainnya dalam al-Qurean, ajaran itu mengisyaratkan agar memilih seorang pemimpin yang jujur dan dapat dipercaya. Perintah ajaran di atas mengandung konsekuensi bahwa kepemimpinan adalah merupakan salah satu prinsip yang harus ditegakkan dalam suatu masyarakat manusia. Setiap orang sesuai dengan kapasitas intelektual dan sosial yang dimilikinya, memiliki hak yang sama untuk menjadi seorang pemimpin. Pola rekrutmen kepemimpinan pun dalam banyak hal dapat berbeda-beda. Karena itu, adalah wajar jika seseorang mengategorikan partisipasi politik khususnya berkaitan dengan masalah kepemimpinan sebagai aktivitas perjuangan untuk menegakkan ajaran agama yang diyakini kebenarannya. Karena itu, menjadi pemimpin dan ikut terlibat dalam proses pemilihannya dipandang sebagai perbuatan ibadah, karena dilakukan dengan mendasarkan pada salah satu perintah ajaran agamanya.

Dalam al-Qur an digambarkan bahwa seorang pemimpin yang baik diperuntukkan bagi masyarakat yang baik pula. Atau dengan perkataan lain, suatu masyarakat yang baik hanya dapat dipimpin dan hanya membutuhkan seorang pemimpin yang baik pula. Masyarakat yang bermoral akan menentukan pemimpin dari kalangan yang bermoral pula.

Di sisi lain, status kepemimpinan yang diberikan kepada manusia tidak lebih hanya sebagai amanat Allah (H.R. Muslim), yang sewaktu-waktu diberikan kepadanya atau (harus) dilepaskannya. Firman Allah:

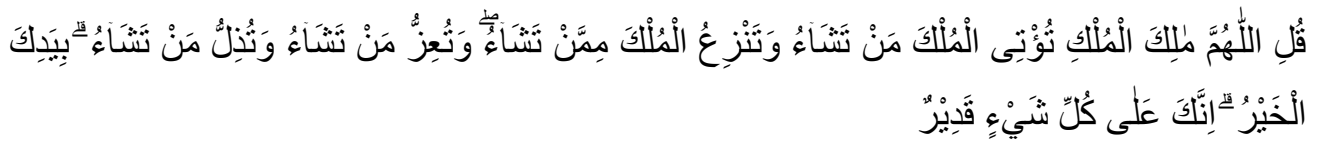


"Katakanlah (Muhammad), "Wahai Tuhan pemilik kekuasaan, Engkau berikan kekuasaan kepada siapa pun yang Engkau kehendaki, dan Engkau cabut kekuasaan dari siapa pun yang Engkau kehendaki. Engkau muliakan siapa pun yang Engkau kehendaki dan Engkau hinakan siapa pun yang Engkau kehendaki. Di tangan Engkaulah segala kebajikan. Sungguh, Engkau Mahakuasa atas segala sesuatu". (Qs. Ali Imron: 26).

Berkenaan dengan amanat khidamah, dalam fungsinya sebagai pemimpin, maka pemimpin diproyeksikan untuk menjadi pelayan (khadim) bagi manusia lain yang dipimpinnya. Pemimpin adalah pelayan publik yang oleh karenanya harus berpihak kepada publik. Jadi, seorang pemimpin itu harus melayani, bukan dilayani. Ia harus menjadi orang yang memberikan pelayanan kepada orangorang yang memberikan kepercayaan kepadanya. Upah yang diterimanya juga merupakan pemberian insentif atas jasa pelayanan yang diabdikan kepada anggota atau masyarakat yang dipimpinnya. Dalam dunia usaha, model kepemimpinan yang mendasarkan kegiatannya pada konsep pelayanan akan memfokuskan perhatiannya pada kepentingan publik yang menjadi konsumen utamanya. Apa yang dianggap penting oleh masyarakat, maka akan dianggap penting pula oleh seorang pemimpin yang menjadi pelayan (khadim) baginya. Masyarakat atau konsumen adalah "majikan" bagi sesuatu institusi yang ada di lingkungannya. Mereka memiliki hak untuk memperoleh kepuasan; dan para pelaku atau pengelola sesuatu institusi berkewajiban untuk melayani sesuatu yang diperlukannya.

Karena itu, besar kecilnya upah yang diperoleh akan bergantung pada prestasi pelayanan yang dilakukannya. Ungkapan "uang adalah sertifikat kreasi sebagai alat tukar yang sah" merupakan cermin kesalingbergantungan antara nilai yang diperolehnya dengan kualitas kerja yang dilakukannya. Dengan demikian, adalah adil jika lebih banyak kreasi yang dilakukan seseorang, maka lebih besar pula sertifikat yang diperolehnya. Sebaliknya, adalah tidak adil jika seseorang yang miskin kreasi, tetapi lebih banyak memperoleh sertifikat. Berkenaan dengan hubungan fungsional antara pemimpin dengan publik yang dipimpinnya, maka proses seleksi seorang pemimpin dilakukan secara demokratis dengan 
mendasarkan mekanismenya pada prinsipmusyawarah. Bermusyawarah pada dasarnya dilakukan untuk menyelesaikan semua masalah yang dihadapi oleh umat manusia. Allah berfirman:

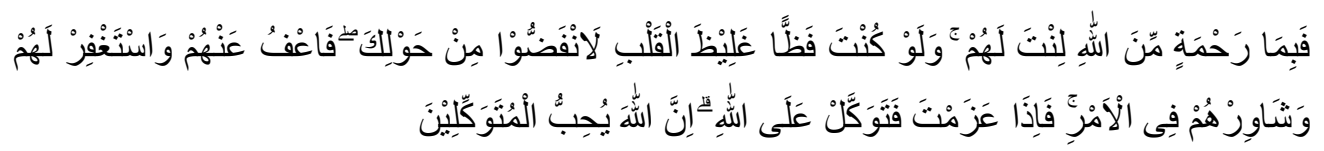

"Maka berkat rahmat Allah engkau (Muhammad) berlaku lemah lembut terhadap mereka. Sekiranya engkau bersikap keras dan berhati kasar, tentulah mereka menjauhkan diri dari sekitarmu. Karena itu maafkanlah mereka dan mohonkanlah ampunan untuk mereka, dan bermusyawarahlah dengan mereka dalam urusan itu. Kemudian, apabila engkau telah membulatkan tekad, maka bertawakallah kepada Allah. Sungguh, Allah mencintai orang yang bertawakal". (Qs. Ali Imran:159).

Ia tidak terbatas hanya pada proses pemilihan seorang pemimpin yang mereka butuhkan. Hanya, karena kepemimpinan merupakan salah satu masalah besar yang dihadapi umat, maka masalah itu pun dilakukan melalui proses permusyawaratan. Seorang pemimpin yang telah dipilih wajib diikuti dan ditaati selama tidak keluar dari garis ajaran serta hukum-hukum yang terkandung di dalamnya. Kedudukan seorang pemimpin berada di bawah Allah dan Rasul-Nya. Bahkan secara eksplisit al-Qur ${ }^{\text {ee }}$ an menyebutkan pemimpin secara -turut setelah Allah dan Rasul, sebagai sosok yang harus ditaati oleh para pengikutnya. Seorang pemimpin bukan hanya bertanggung jawab pada kepentingan politis keduniaan, tetapi juga urusan spiritual. Namun demikian, kalangan rakyat, peran pemimpin masih relatif lebih lentur, sehingga fungsi ganda itu dapat diperankan oleh dua sosok yang berbeda. Keharusan taat kepada seorang pimpinan tidak berarti bahwa para pengikutnya tidak bisa mengkritisi mekanisme kepemimpinan yang diperankannya. Fungsi kontrol harus tetap dimainkan oleh komunitas yang dipimpinnya. Terlepas dari persoalan apakah fungsi kontrol ituharus terlembaga atau tidak. 


\section{Memahami Makna Pendidikan Islam}

Muhaimin (2003) mengartikan pendidikan Islam dengan tiga hal: 1) pendidikan dalam (sejarah) Islam, yaitu pendidikan yang lahir dan berkembang seiring dengan dinamika dan perkembangan (sejarah) Islam; 2) pendidikan perspektif Islam berarti pendidikan dalam pandangan al-Qur an dan al-Hadist sebagai sumber pokok ajaran agama Islam; dan 3) pendidikan agama Islam yang berarti menjadikan Islam sebagai way of life atau pandangan hidup bagi para pemeluknya. sesungguhnya menunjukkan keluasan bahasan dan cakupan dari pendidikan Islam itu sendiri sehingga dibutuhkan kehati-hatian dalam mempersoalkan dan mengkaji pendidikan Islam itu sendiri.

Dalam kerangka peraturan perundang-undangan pendidikan di Indonesia (UU No. 20 tahun 2003), kata pendidikan Islam selalu diidentikkan dengan pendidikan agama dan keagamaan. Pendidikan agama yang dimaksud adalah pendidikan agama di Madrasah dan sekolah dalam pengertian pendidikan agama pada jalur pendidikan formal. Sementara pendidikan keagamaan yang dimaksud adalah pendidikan agama di pesantren, Madrasah diniyah, majlis ta'lim dan semisalnya yang notabenenya berada pada jalur pendidikan non-formal.

Secara konsep, penyebutan pendidikan Islam tentu akan mengarah pada tiga term yang umum digunakan, yaitu tarbiyah, ta"lim dan ta"dib. Penggunaan masing-masing istilah berimplikasi pada banyak hal. Ketiganya menjadi discourse yang tidak pernah berujung pada sebuah kesepakatan mengenai apa istilah yang paling tepat digunakan untuk memaknai pendidikan Islam.

Konsep tarbiyah diusung oleh Ahmad Fuad al-Ahwani (Tt.), Ali Khalil Abu al-Ainain (1980), Muhammad Athiyah al-Abrasyi (1950 \& 1975) dan Muhammad Munir Mursyi (1987) serta Mahmud Yunus. Mereka menggunakan kata tarbiyah untuk arti pendidikan.

Menurut Muhammad Attiyah al-Abrasyi istilah al-Tarbiyah lebih tepat digunakan dalam konteks pendidikan Islam daripada al-Ta"lim. Keduanya memiliki perbedaan yang mendasar. Tarbiyah berarti mendidik, sedangkah Ta'lim berarti mengajar. Mendidik berarti peserta didik dengan segala macam cara, supaya dapat mempergunakan tenaga dan bakatnya dengan baik, sehingga 
mencapai kehidupan yang sempurna di dalam masyarakat. Oleh karena itu pendidikan mencakup pendidikan akal, kewarganegaraan, jasmaniyah, akhlak, dan kemasyarakatan. Sementara al-Ta"lim hanya merupakan salah satu bagian dari sarana-sarana pendidikan yang bermacammacam itu. Dalam hal ini Mahmud Yunus sependapat dengan al-Abrasy, bahwa al-ta"lim adalah salah satu sarana di antara sarana-sarana altarbiyah. At-Talim secara khusus hanya menyampaikan ilmu pengetahuan ke dalam pikiran dan mengisi ingatan-ingatan anak dengan masalahmasalah ilmu pengetahuan dan seni. Sarana-sarana dalam Ta"lim itu ada tiga, yaitu: guru, murid dan ilmu pengetauan.

Sementara itu konsep ta"lim yang diusung oleh Abdul Fattah Jalal (1977), menyandarkan pendapatnya pada ayat al-Qur an yang berbunyi:

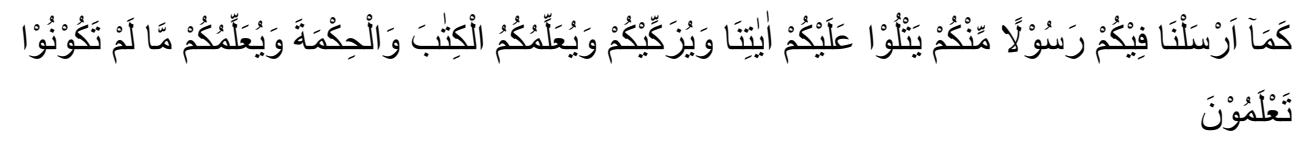

“Sebagaimana Kami telah mengutus kepadamu seorang Rasul (Muhammad) dari (kalangan) kamu yang membacakan ayat-ayat Kami, menyucikan kamu, dan mengajarkan kepadamu Kitab (Al-Qur'an) dan Hikmah (Sunnah), serta mengajarkan apa yang belum kamu ketahui”. (Qs. Al-Baqarah:151).

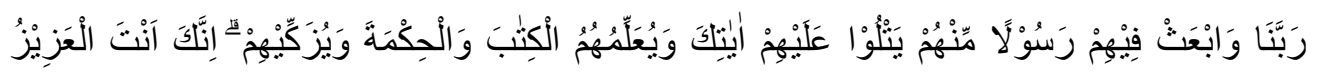
الْحَكِيْمُ

"Ya Tuhan kami, utuslah di tengah mereka seorang rasul dari kalangan mereka sendiri, yang akan membacakan kepada mereka ayat-ayat-Mu dan mengajarkan Kitab dan Hikmah kepada mereka, dan menyucikan mereka. Sungguh, Engkaulah Yang Mahaperkasa, Mahabijaksana.” (Qs. Al-Baqarah: 129).

Sedangkan Syed Muhammad Naquib al-Attas (1992: 2) mengatakan bahwa pendidikan Islam adalah al-ta"dib, bukan al-Tarbiyah dan bukan pula alTa"lim. Al Attas mendasarkan analisisnya atas konsep semantik dari Hadis Rasulullah saw yang diriwayatkan oleh Ibn Mas"eud, ketika al-Qur an sendiri digambarkan sebagai undangan Allah swt. Untuk menghadiri suatu perjamuan di atas bumi, dan sangat dianjurkan untuk mengambil bagian di dalamnya dengan cara memiliki pengetahuan yang benar tentangnya. 


\section{G. Implikasi Perspektif Teologis terhadap Kepemimpinan dalam Pendidikan Islam}

Dalam pendidikan Islam sosok pemimpin dapat diidentifikasi pada diri seorang guru. Guru adalah pemimpin. Dalam pendidikan Islam, term guru dikenal dengan istilah mu"allim, mudarris, ustadฆ, murabby, muaddib, mursyid, dan syaikh (Muhaimin, 2003). Istilah-istilah tersebut memiliki akar kata yang berbeda sehingga berimplikasi pada perbedaan makna. Hal ini memiliki konsekuensi logis yang harus dijalankan oleh seorang guru sebagai pemimpin dalam pendidikan Islam, yaitu terkait dengan tugas, peran, fungsi dan tanggung jawab yang harus dipikul. Meskipun demikian, semua istilah tersebut memiliki konotasi yang sama dalam konteks mengisi atau menempati ruang yang ada dalam pendidikan Islam sesuai dengan porsinya masing-masing.

Kata mu" allim berasal dari kata ,allama-yu" allimu-ilman wa mu'alliman yang berarti menangkap hakekat sesuatu. Kata mu'allim sebagai subjek atau pelaku memiliki pengertian bahwa sebagai guru seseorang dituntut untuk dapat menjelaskan hekekat sesuatu, baik Kata mu'allim berasal dari kata ,allama-yu'allimu ,ilman wa mu'alliman yang berarti menangkap hakekat sesuatu. Kata mu'allim subjek atau pelaku memiliki pengertian bahwa sebagai guru seseorang dituntut untuk dapat menjelaskan hekekat sesuatu, baik secara teoritis maupun praktis. Peran "kepemimpinan" guru dalam hal ini adalah mengajarkan hakekat sesuatu (maahiyyah) kepada anak sehingga anak dapat memiliki pemahaman yang utuh dan benar tentang diri dan realitas yang ada.

Kata mudarris berasal dari kata darasa - yadrusu-darsan-wa durusan wa dirosatan, yang berarti menghapus, melatih, mempelajari. Berangkat dari pengertian ini, tugas guru sebagai pemimpin adalah mencerdaskan siswa, menghapuskan segala bentuk kebodohan dan kejahilan yang ada, melatih dan mengajarinya dengan berbagai pengetahuan sehingga bakat dan potensi yang dimilikinya dapat dimunculkan dan dikembangkan.

Kata ustadz dalam term arab biasanya digunakan untuk panggilan seorang professor di perguruan tinggi. Ketika kata itu digunakan untuk memaknai tugas kepemimpinan guru terkandung maksud bahwa seorang guru dituntut untuk 
selalu mengedepankan profesionalisme dalam berbuat dan bekerja. Profesionalisme akan muncul manakala seorang guru memahami dunia yang digelutinya, mengerti tugas dan fungsinya serta memiliki komitmen untuk selalu tekun mengemban tugasnya.

Kata murabby berasal dari kata rabba-yurabby yang berarti mengasuh, mengelola, memelihara. Kata murabby memiliki akar kata yang sama dengan rabbul alamin, Tuhan Pencipta dan Pemelihara alam semesta. Kata tersebut juga memiliki akar kata yang sama dengan tarbiyah yang biasa digunakan orang untuk memaknai kata pendidikan Islam. Kepemimpinan seorang murabby atau guru dalam pendidikan Islam dituntut untuk dapat memelihara, mengasuh dan menyiapkan anak didik untuk dapat secara kreatif mengembangkan potensinya sebagaimana rabb Tuhan Pencipta alam semesta ini memelihara dan mengasuh makhluk ciptaanNya.

Kata muaddib memiliki akar kata addaba - yuaddibu. Kata ini memiliki akar kata yang sama dengan adab dan peradaban, Guru sebagai seorang muaddib dalam melaksanakan tugas kepemiminan dituntuk untuk dapat mengembangkan seluruh potensi kemanusiaan manusia tidak saja aspek jasmaniahnya semata akan tetapi juga aspek rohaniyahnya. Esensi kemanusiaan manusia sesungguhnya ada pada moral dan akhlaknya. Ketika kemanusiaan manusia sudah dapat dikembangkan maka akan menghasilkan sosok beradab dan bermoral (muslim, mu'min dan mubsin) yang dikemudian harinya dapat membangun sebuah peradaban yang maju dan bermoral pula (al-Attas, 2003).

Kata mursyid, biasanya digunakan dan dikenal dalam term thariqah, salah satu ajaran dalam tasawuf. Posisi seorang mursyid dalam ajaran thariqoh adalah posisi yang sangat penting. Dalam bertarikat, seseorang tidak akan sampai kepada tujuan ketika ia tidak di "restur" oleh seorang mursyid. Seorang guru dalam melaksanakan kepemimpinan dalam pendidikan Islam, bertugas dan berfungsi sebagai seseorang yang mampu membimbing dan mengarahkan siswanya terutama pada bimbingan aspek moralitas dan spiritualitas, sehingga anak tidak saja ,tajam' dalam aspek intelektualitasnya semata akan tetapi juga memiliki kepekaan moral dan spiritual. 
Muhaimin (2003) menyebut dua tugas utama guru yaitu; pertama, tugas kependidikan dan kedua, tugas kemanusiaan. Muhaimin dalam hal ini melihat dan memposisikan guru tidak saja sebagai pendidik dalam lembaga pendidikan formal saja, tetapi ia juga memiliki peran dan posisi penting di masyarakat sebagai figure yang diteladani oleh masyarakat. Dalam perspektif ini dan juga istilah-istilah yang muncul di depan serta tugas yang diemban sebagai konsekuensi istilah yang digunakan, benar bahwa pendidik dalam pendidikan Islam adalah sebagai model.

\section{KESIMPULAN}

Kepala Madrasah sebagai penggerak utama dalam sebuah kepemimpinan lembaga dalam islam, pemimpin ada hakekatnya adalah seseorang yang mempunyai kemampuan untuk mempengaruhi perilaku orang lain di dalam kerjanya dengan menggunakan kekuasaan. Guru sebagai pemimpin dalam pendidikan Islam dengan istilah yang digunakan memiliki implikasi dan konsekuensi moral, profesional, dan spiritual. Konsekuensi tersebut menuntut komitmen kuat oleh seorang guru, sementara itu komitmen guru tidak mungkin terbangungunn apabila manakal basis islam atau teologis untuk melaksanakan tugas atau kewajibannya baik sebagai hamba Allah, maupun sebagai khalifah Allah di muka bumi

\section{DAFTAR PUSTAKA}

Al-'Ainain, Ai Khalil Abu. (1980). Falsafah Al-Tarbiyah Fi al-Quran Al-karim. Baerut: Dar Al-Fikr al-A'raby.

al-Abrasyi, Muhammad Athiyah. (1975). al-Tarbiyah al-Islamiyah wa falsafatuha Mesir: Isa al-Baby.

al-Abrasyi, Ruh. (1950). Cet Ke-1. al-Tarbiyah al-Islamiyah. Kairo: Dar al-Kutub alArabiyah.

al-Ahwani, Ahmad Fuad. (2003). al-Tarbiyah fi al-Islam. Mesir: Dar al-Ma arif. Tt. Daud, Wan Mohd Wan. Filsafat dan Praktik Pendidikan Islam Syed $M$. Naquib Al-Attas. Bandung: Miza.

Umam, Khaerul. (2010). Perilaku Organisasi. Bandung: Pustaka Setia.

Fattah, Nanang. (2004). Landasan Manajemen Pendidikan. Bandung: Remaja Rosdakarya. 
Jalal, Abdul Fattah. (1997). Min al-Usul at-Tarbiyah fi al-Islam. Mesir: Dar alKutub alMisriyah.

Keating, Charles J. (1990). Kepemimpinan. Yogyakarta: Kanisius.

Muhaimin. (2003). Wacana Pengembangan Pendidikan Islam. Surabaya: PSAPM.

Mursyi, Munir. (1987). al-Tarbiyah al-Islamiyah Usuluba wa Tatawnuruha fi alBilad al-, Arabiyah. Mesir: Dar al-Ma'arif.

Permadi, K. (1996). Pemimpin dan Kepemimpinan dalam Manajemen. Jakarta: Reneka Cipta.

Robbins, Stephen P. (1991). Management, New Jersey: Prentice-Hall,inc.

Soebahar, Halim. (1992). Wawasan Baru Pendidikan Islam. Pasuruan: PT Garoeda Buana Indah.

Wahab, Abdul Azis. (2008). Anatomi Organisasi dan Kepemimpinan Pendidikan: Telaah terhadap Organisasi dan Pengelolaan Organisasin Pendidikan. Bandung: Alfabeta.

Warren, Bennis. (2000). Kepemimpinan: Strategi dalam Mengemban Tanggung Jawab. Jakarta: Prenhallindo. 